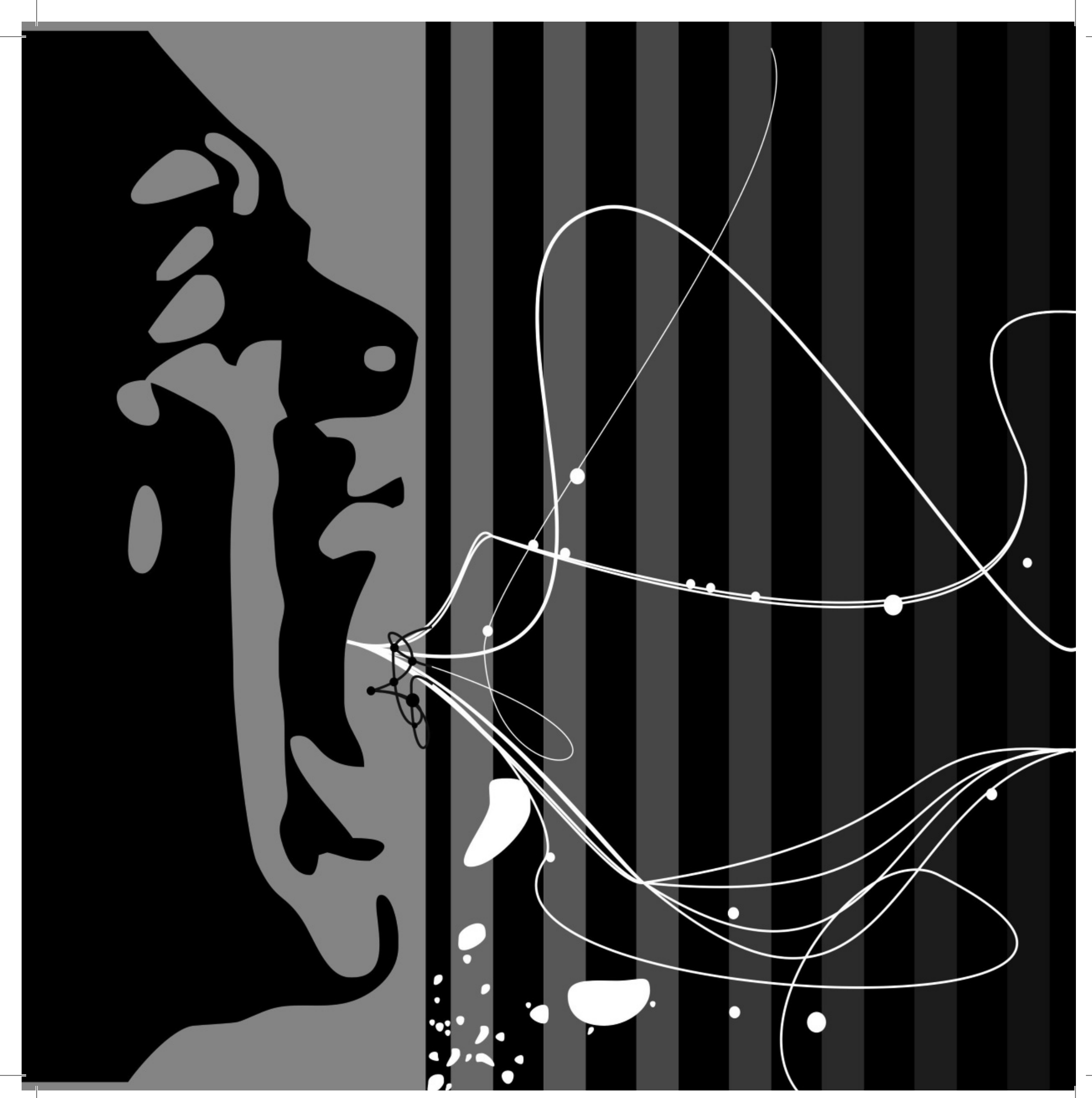




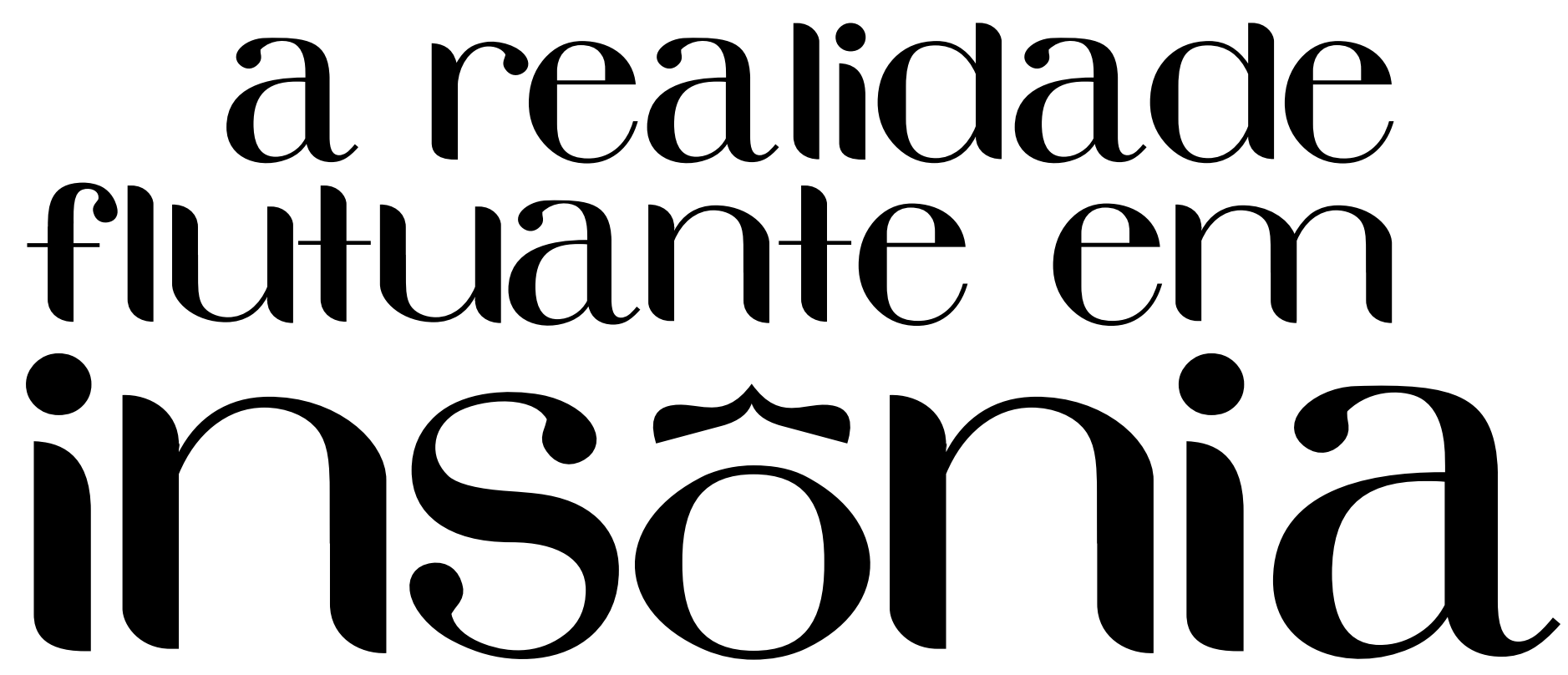

\section{Edilson Dias Moura}

\section{Resumo}

O início do século XX marca, tanto na História como nas artes, o princípio de transformações profundas em todas as instâncias das sociedades. Este ensaio discute como é possível que as chamadas vanguardas, ou o
Modernismo, estejam presentes na obra de um autor como Graciliano Ramos, mesmo tendo este manifestado pouco interesse por movimentos dessa natureza. A resposta, a nosso ver, seria o próprio contexto histórico da produção artística, de qual nenhum autor àquela altura podia prescindir, tampouco não tirar dele suas experiências práticas de realização.

\section{Palavras-chave:}

modernidade, maquinismo, ponto de vista.

1 Mestrando do Departamento de Letras Clássicas e Vernáculas do

Programa de Pós-Graduação da Área de Literatura Brasileira. Bacharel em

Letras pela Universidade de São Paulo. Contato: edilson.moura@usp.br 


\begin{abstract}
The early twentieth century marks historical events around the world, producing deep changes in the human sensibility. The vanguard and the modernist literature were some theoretical manifestations influenced by those changes. However, even though a writer like Graciliano Ramos never had showed interest for modernism - considering he was absolutely against those tendencies- his short tales present many points of comparison with vanguard manifest. This essay intends to investigate how it was possible, considering the effects of technologic advance like a phenomenological and historical equalizer point of view.
\end{abstract}

\section{Key words:}

modernism, machinary, point of view.

\section{Introdução}

Eunaldo Verdi, em Graciliano Ramos e a crítica literária, publicado em 1989 pela editora da UFSC, aponta que a crítica, em abordagem à obra do romancista alagoano, pouco se deteve em seus contos. Houve um pequeno interesse sim, mas, dos 177 estudos coletados até a data de finalização de sua pesquisa -, apenas seis contemplavam os trabalhos desse gênero. Posteriormente, refinando os pressupostos para uma melhor caracterização das tendências críticas, esse número de abordagens desaparece, saltando aos olhos os 63 trabalhos dedicados à obra em conjunto e 30 sobre a vida do autor; distribuindo-se o restante em abordagens específicas, nas quais é quase unânime o pressuposto da experiência vivida pelo autor na elaboração e composição de suas obras em termos biográficos.

Nesse universo, os contos cumpririam a mera função de argumento do que se propôs para o geral. Um exemplo dessa via nos é dado pelo trabalho de Nelly Novaes Coelho: ao lidar não só com a incomunicabilidade no universo do romance de Graciliano, aponta também para a impossibilidade de realização das relações amorosas, fazendo um contraponto entre o conto "O ladrão" e o capítulo final de Vidas secas. Ainda que essa aproximação seja válida, o conto vai mais além; relaciona-se aos outros textos de Insônia em que as ocorrências ou temas noturnos lhe servem de baliza, o que nos permite inferir que há ali algo de programático, em que realidade e aspectos do sonho se entrelaçam e põem em dúvida o que seria o real perceptível. Sendo assim, os contos podem render mais debate do que imaginamos, muito embora tenham sido deixados de lado por privilegiarem-se as abordagens biográficas ou a obra do autor na totalidade.

Quanto aos estudos que propõem vislumbrar na ficção do autor suas características pessoais, portanto, não nos parece necessário dizer mais do que Verdi já revelou; no mais, não é nosso intuito aqui esse tipo de abordagem, visto que parece mais relevante o fato de que Graciliano vivia nesse instante da história entre revoluções de toda ordem, desde "nosso pequeno fascismo tupinambá" à 
Segunda Grande Guerra, em que inúmeras experiências tecnológicas, como o emprego sistemático de máquinas em atividades diversas, até então inimaginável ou apenas na ficção do século XIX, acarretaram mudanças profundas no modo de sentir e perceber a realidade ${ }^{2}$.

Dessa característica parte a hipótese de que Graciliano não tenha se abastecido de nenhuma das teorias vanguardistas, de fato, conforme a crítica aponta frequentemente. Contudo, embora o autor jamais tenha se referido a elas senão de modo desinteressado, é muito pouco provável que não as tenha assimilado indiretamente, por impregnação do contexto histórico. Daí o pressuposto de que os contos concentrem e acumulem inovações e experimentos que nos romances se dissiparam pela clareza de seu estilo e pela extensão dos textos nesse gênero. E "Baleia", publicado em jornal antes de tornar-se o capítulo mais célebre de Vidas secas - também um dos textos da antologia intitulada Histórias agrestes -, evidencia que eles não só foram ponto de partida de seus romances, revelando a importância de estudar o Graciliano contista de modo diferente, como são neles também que se manifestam de modo mais concentrado as inovações técnicas e formais do autor. Note-se, por exemplo, em "Baleia", que antecedeu o romance, como a protagonista apresenta rupturas irrefutáveis no modo de representação de animais na literatura, o que, consequentemente, afetaria também a noção de verossimilhança padrão.
Comparando Baleia ao cãozinho Quincas Borba, de Machado de Assis, por exemplo, vemos que é só a partir das hipóteses e receios de Rubião que o famoso vira-lata produz nexo; de modo que não há nenhuma semelhança entre eles. Isto é, o simpático herdeiro da fortuna do filósofo do humanitismo está limitado e delimitado pela condição animalesca, em que Rubião insufla algo que só a ele diz respeito; enquanto que entre Baleia e o narrador há quase um sincretismo absoluto em termos de percepção das coisas e dos homens a seu redor, interagindo juntamente com todas as suas expectativas e esperanças de modo semelhante, a ponto de se destacar tanto de Fabiano e sua família como do narrador com uma existência autônoma no conto. Mas, se essa constatação soar puramente argumentativa e hipotética, justificando a abordagem que vamos adotar na análise logo mais à frente, o certo é que ela nos permite pelo menos evitar o paralelismo rigoroso "vida e obra" e nos exija mais atenção à elaboração técnica textual; portanto, sem que nos preocupem as tradicionais contradições geradas entre o nome Graciliano Ramos e certas particularidades de seus textos. Bastando lembrar, para isso, dos trabalhos do romancista publicados na revista Cultura política, do Estado Novo, e da enorme dificuldade de estudá-los sem que se esbarre nas opções políticas do autor em contraste com o programa ideológico daquele governo; 
o que tornou intocáveis certos aspectos dos textos por se ter uma imagem generalizada do autor construída à base da pura especulação biográfica. ${ }^{3}$ Fundindo-se à produção artística, a biografia gerou um nome, Graciliano Ramos, que não vamos identificar nos contos. E parece-nos que, quanto mais a imaginação Ihe foi exigida, mais ele se afastou daqueles pressupostos básicos de "experiência vivida como base de sua prática artística", a ponto de, em A terra dos meninos pelados, revelar-se um Graciliano Ramossuigeneris: "Embora aíse conservem os valores da vernaculidade da língua literária, (...) a verossimilhança realista é descartada, a forma/gênero são liberados de convenções, desaparecendo também o pressuposto da sinceridade e da experiência vivida pelo escritor." " Há, portanto, sensível mudança técnica empregada pelo autor conforme o gênero textual em que trabalhava, relativando bastante as abordagens totalizadoras e que creem poder harmonizar num mesmo lugar elementos claramente díspares em termos epistemológicos.

Finalmente, se há certo desencontro entre o romancista e o contista, certos pressupostos devem ser revistos antes de qualquer tentativa de análise e interpretação nesse gênero. O risco de forçarmos o texto a se conformar com o que se generalizou a partir de outras atividades do autor, para não nos afastarmos demais do

O pesquisador Thiago Mio Salla, em sua tese de doutorado $O$ fio da navalha: Graciliano Ramos e a revista Cultura Política, pela Escola de Comunicação e Artes da USP, tem apontado essa dificuldade de se distinguir o Graciliano da biografia pessoal e o cronista da revista Cultura Política, gerando uma postura de defesa do autor alagoano desnecessária senso comum, é enorme, o que nos esforçaremos para evitar aqui.

\section{"Um contista medíocre"}

Sãodoisoslivros de contos deGraciliano: Insônia, de1946, e Alexandre e outros heróis, de 1962. Não nos deteremos em datas, sabido que os contos, antes de obterem os formatos atuais, foram publicados em jornais, reunidos em volumes com outros nomes. Como exemplo, em 1944 foi publicado o Histórias de Alexandre, hoje Alexandre e outros heróis. Ocupar-nos-emos, portanto, com o estilo e a técnica empregada nos contos e o motivo por que não obtiveram as atenções da crítica em geral. Nossa perspectiva de análise norteia-se pela tese de que a qualidade deles não repousa na perquirição de "um momento significativo e literariamente depurado", apontados como fulcral ao gênero por Antonio Candido em Fiç̧ão e confissão; caracterização mesma ligada ao conto realista e que, por falta deles, conduziria o autor a resultados medíocres em relação aos romances. Mas o que se percebe, ao contrário, é que a realidade, enquanto convenção genérica em seus contos, perde o caráter ordinário da análise factual, ganhando relevância o como se chega aos fatos, sem deter-se neles. O que, de modo geral, quando se fala de objetividade e de clareza em Graciliano Ramos, revela certa acomodação às raias do Naturalismo e do Realismo sem se perguntar de que tipo de realidade Graciliano trata, nem a que convenção literária esta se ligaria para alcançar essa objetividade e clareza; e, mais importante, quais seriam as condições concretas e históricas de prática artística 
nesse momento? Visto que a realidade objetiva, como a escrita, sofre profundos embargos no século $X X$, não seria possível, ainda que o autor aluda a modelos, escritores e obras do século XIX, que a linguagem antes tida como a mais adequada para fins literários gerais não sofresse significativas modificações. O Modernismo não foi um movimento artístico isolado dos fatos históricos e das profundas mudanças sensoriais por quais as sociedades passaram; pelo contrário, ele estava totalmente integrado nelas. E tudo isso teria contribuído para que alguns autores reproduzissem em seus textos (o escritor sempre dialoga com o leitor de seu tempo) certos aspectos modernos ${ }^{5}$ despercebidamente. É por isso que nem todos os escritores claramente modernistas atingem a qualidade literária que lhes poderia ser atribuída apenas pela mimese direta de tal realidade ou pelo emprego de uma linguagem artística dita moderna: a percepção nova só é completa, na literatura, com a da mudança linguística ou formal que acompanha tais transformações de percepção. Assim sendo, ainda que possamos perceber em muitas obras que se está dialogando sobre este novo universo de possibilidades, isso não é o bastante se a partir de uma linguagem inapta a alcançá-lo correspondentemente e vice-versa. Por isso a inquietação de Lafetá ter se

\footnotetext{
5 Os termos Modernismo e moderno, aqui empregados, têm como significação não só aquele feixe de definições mais diluídas historicamente como base do movimento de 22, mas também todas as práticas e hipóteses marginalizadas que o termo Modernismo põe fora de seu escopo. Isto é, ao privilegiarem-se algumas ideias, alijaram-se outras hipóteses e práticas próprias do período, deixando de lado o fato de que elas fossem também a concretização de uma nova forma de experimentar sensorialmente a realidade e um meio de intervenção amarrada ao seu tempo, as quais hoje se têm designado, acrescentando o prefixo neo, Realismo, Naturalismo, Simbolismo etc., produzindo certo anacronismo em escala menor, por isso mesmo mais difícil de se perceber.
}

manifestado da seguinte forma: "Meu problema era saber em que medida o tradicional e o moderno (o neorealismo e as conquistas literárias das vanguardas) se combinavam em Graciliano Ramos." ${ }^{\prime 6}$

O Modernismo, que para muitos parecia facilitar a arte, pelo contrário, trouxe-lhe mais complicações do que as dificuldades impostas por um modelo tradicional disseminado. $A$ arte, no século $X X$, tornouse terrivelmente difícil, exigindo dos artistas um tipo de conhecimento ligado mais ao momento de execução (isto é, ligado à percepção do que se havia escondido debaixo do tapete literário), partindo da oposição total a qualquer desejo de ser interpretada ou consumida de modo imediato, segundo valores preestabelecidos (é uma prática que repele a compreensão imediata e qualquer modelo de interpretação filosófico que lhe preexista; o que produz a sensação desconfortável de insegurança a respeito do que esteja representado em tal universo artístico); e os modelos de análises ligados ao passado, facilitadores da atividade crítica, promoveram ambiguidades ainda hoje não resolvidas. Ou melhor, se impuseram de tal modo que a sua permanência não poderia resultar em outra coisa senão o desaparecimento do Modernismo enquanto fenômeno global das sociedades de produção e consumo capitalista; reduzindo-o a umas poucas obras - dignas, é verdade, de compor o nosso cânone literário -, mas que não refletem de modo algum todo o conjunto de práticas existentes que compreenderiam

\footnotetext{
João Luis Lafetá, "Três teorias do romance: alcance, limitações complementaridade", p. 284.
} 
as transformações ocorridas nesse século. Dado esse contexto histórico de produção, não seria sensato partir para a análise de Insônia em busca de "unidade", "objetividade" e "clareza" sem adequá-las aos aspectos gerais da realidade característicos do século XX. No conto "Insônia", por exemplo, deparamo-nos com uma identidade de sujeito situado na semiconsciência, entre o sonho e a realidade; e por esse entremeio é que a suposta garantia de realidade, de segurança e conforto no mundo passa a ser questionada. A objetividade, nesse caso, se realiza por uma "deformidade" da forma de representação e do objeto focado. E não parece gratuito tal aspecto, muito próximo do que Breton defendeu em seu "Manifesto do Surrealismo".

Foi a título muito justo que Freud fez sua crítica ao sonho. É inadmissível, com efeito, que essa parte considerável da atividade psíquica (pois que pelo menos desde que o homem nasce até que morre o pensamento não apresenta qualquer solução de continuidade, a soma dos momentos de sonho, do ponto de vista do tempo, considerando-se apenas o puro sonho, aquele do sono, não é inferior à soma dos momentos de realidade, limitemo-nos a dizer: momentos de vigília) tenha chamado ainda tão pouca atenção. ${ }^{7}$
Isto é, entre a percepção do encadeamento lógico atribuído à realidade, de modo consequente, e a ilogicidade do sonho haveria mais semelhanças do que se imaginava. E a inversão da perspectiva tomada diante da suposta realidade revelava que os fatos aparentemente objetivos estariam impregnados de uma compreensão que os determinavam no tempo e no espaço em conformidade com sistemas filosóficos e ideológicos a fim de mascará-los e propiciar conforto e segurança no mundo. Tal percepção implicou também em que a representação simbólica desse novo universo, em termos artísticos, não suportaria nenhum modelo preconcebido. Nesse panorama de indefinição, não é de se estranhar que a literatura passasse a integrar em si mesma suas próprias hipóteses.

Em Graciliano isso ocorre com frequência, e vários críticos já se referiram à metaliguagem nos seus textos. Do primeiro conto de Insônia até "Paulo", a perspectiva "noturna" de perquirição do real é nítida; cuja insolubilidade do contínuo tanto na cadeia dos eventos como na temporalidade é particularidade essencial. Mais da metade do livro, portanto, se passa à noite, na sonolência ou durante a modorra de personagens aparentemente delirantes. Algo, pois, de muito programático neste livrinho: a ideia de divisão das perspectivas, levada ao extremo em "Uma visita", sugere uma espécie de cubismo do foco narrativo, apagando "o motivo literário factível", fragmentando-o por meio do deslocamento das perspectivas dos personagens, que giram, como num caleidoscópio, em torno de nada; isto é, não há um motivo literário específico dominado 
por um ponto de vista que o perscrute; apenas efeitos coloridos, sonoros e visuais das mudanças de perspectivas acompanhados pelo olhar do narrador. Na verdade, ouvimos e ficamos sem saber de nada. Os atores do conto reagem uns aos outros como se tudo andasse perfeitamente bem, dentro da normalidade, como nos contos de Artur de Azevedo ou Machado de Assis, que põem seus personagens em perseguição a ideias fixas e claras de modo a desvendá-los enquanto mistérios. Mas isso não se dá na totalidade de contos de Insônia: o grande mistério, o que fica a se desvendar, é a possibilidade de que a realidade não passe de uma total falta de nexo, fragmentada pela percepção particular de cada um, segundo seus próprios propósitos. Enquanto na superfície social tudo vai dando a entender que sim, que há uma realidade coerente, linear, concisa, clara, evidente, integrada e que convergiria para cada um no mesmo ponto, é o contrário disso que vai ser notado; e embora não haja nenhuma convergência e a total fragmentação dos sentidos, há nexo entre eles, e em tais nexos o espanto de que a realidade flutua e se modifica, como nos sonhos, sem nenhuma solução de continuidade. Assim, à mercê da disseminada ideia de que Graciliano "abominava o modernismo", não há meios que nos possam levar à compreensão desses contos senão por pressupostos modernos e vanguardistas: é o texto que se nos impõe. E tal prática, ainda inominável, não se assemelha à de Kafka ou à de Joyce ${ }^{8}$ Entre estes autores e o Graciliano contista não está exatamente o

8 "Tudo depende do ângulo de visão e da compreensão dos problemas. Por outro lado, nada seria mais errôneo do que afirmar que Ulisses apresenta de fato um relato realista." Erwin Theodor Rosenthal, OUniverso fragmentário, p. 17. desconforto de se perceber um mundo perturbador e aparentemente sem nexo?

\section{"Insônia": no mundo da lua ou no sonho da vida}

"Insônia" nos dá bem a ideia que atravessará quase todos os outros contos. Sem mais nem menos, o personagem-narrador é aparentemente arrancado do sono profundo, no meio da noite, pela pergunta "'Sim ou não?' Esta pergunta surgiu-me de chofre no sono profundo e acordou-me. A inércia findou num instante, o corpo morto levantou-se rápido, como se fosse impelido por um maquinismo."9 Não é difícil ligarmos a pergunta ao "maquinismo" da "escolha" e ao do próprio mundo moderno. Aliás, óbvio, já que a partícula "como" estabelece a relação de semelhança: o primeiro responsável direto pelo despertar de chofre de um mundo automatizado; o segundo elemento apontando para a decisão já tomada na pergunta dentro do contexto em que se segue: a máquina não tem escolha, e o que seria próprio do humano vai ser suprimido ao se apresentar como "deformação". A questão será sobre "o que" exatamente se decidir em função da pergunta ser feita em momento inoportuno (fora de um contexto dado como "natural"), mas que, no entanto, é parte do universo humano. Isso surge pela falha da máquina cronológica do calendário e dos dias, das horas fixas do trabalho e do sono no universo social, não das possibilidades geradas pela condição humana. Entre a

\footnotetext{
Graciliano Ramos, Insônia, p. 7. Doravante não mais citaremos as referências e páginas dessa obra, facilmente localizáveis em qualquer
} volume. 
"inércia", de qual o "corpo morto" sai e reanima-se, e a reentrada à consciência, abre-se um lapso temporal e espacial em que o narrador ouve a pergunta "Sim ou não?" e a compara a "Uma garra segurando-me os cabelos, puxando-me para cima, forçando-me a erguer o espinhaço". Daí o estado de semiconsciência se desvela: ao notar que a pergunta era absurda, não lhe resta outra solução senão voltar a dormir. Isso se o maquinismo não tivesse falhado; se se estivessem sincronizados o tempo do relógio humano e o do relógio social: levantaria como máquina; como em todas as manhãs.

Em Biologia, o relógio celular animal ou vegetal é chamado de cercadiano, isto é, cerca de um dia, e funciona de modo diferente dos relógios mecânicos, cuja marcação do tempo é determinada socialmente e a que devemos nos adequar. O personagem pretende dormir, obedecer ao tempo social, mas não pode, ligando a esse aspecto o próprio título do conto: "Insônia", em que o indivíduo, fatigado pelas atividades diárias do trabalho e dos compromissos sociais, se encontraria em um tempo e espaço absolutamente desvinculados das ações práticas do mundo, mas não das ações do intelecto ou do pensamento que fluem continuamente em qualquer tempo ou lugar. "Mas o desgraçado corpo está erguido e não tolera a posição horizontal. Poderei dormir sentado?" Ocorre então a perspectivação da imagem do personagem num estado, embora natural, perturbador: concluído que não pode dormir sentado, estando ele certo disso, voltaria a deitar-se. Mas o os tique-taques do relógio e teme que dormirá sentado. Ora, o tempo aí não é mais do relógio social. É o tempo do sujeito, não o do cidadão. É o tempo do sonho, em que dormir se torna ilógico, impossível. Já aí se atingiu o limite máximo das possibilidades.

Esse quadro não nos é dado gratuitamente. É verossímil: estado em que não sabemos que estamos dormindo, ou em que imaginamos que já estamos acordados quando permanecemos dormindo. Tal evento assemelha-se ao sonambulismo. Mas, aí na ficção, é uma forma de representação de um nível de discurso dentro de outro, cuja inversão do que estaria contido num estado, e o que o contém, possibilita comparações.

Assombra-se, aí, o personagem e deseja estar acordado: "(...) levantar-me-ei tranquilo com os rumores da rua, os pregões dos vendedores, que nunca escuto." Isso se o maquinismo não tivesse falhado. Esse encadeamento do real dentro do sonho vai tornar-se mais agudo ainda quando a realidade for percebida como apenas plataforma frágil da razão em que nossa consciência se sustenta pela repetição exaustiva:

Certamente aquilo [a pergunta] foi alucinação, esforço-me por acreditar que uma alucinação me agarrou pelos cabelos e me conservou deste modo, inteiriçado, os olhos muito $\underline{\text { abertos }}^{10}$, cheio de pavores. Que pavores? Por que tremo, tento sustentar-me em coisas do passado, frágeis, teias de aranha? Sim ou não?

10 Grifo meu, doravante adotado como padrão nesse ensaio. 
Estarei completamente doido ou oscilarei ainda entre a razão e a loucura? Estou bem, é claro. Tudo em redor se conserva em ordem: a cama larga não aumentou nem diminuiu, as paredes sumiram-se depois que apertei o botão do comutador (...)

A sensação de estar com os olhos "muito abertos" deriva de que o narrador está dormindo. Tivesse ele, de fato, acordado, os olhos estariam entreabertos, semisserrados. Junte-se a isso o fato de que ele sonha com a realidade: as coisas se mantêm em ordem, a cama, as paredes etc., evidenciando que o lugar do sonho é seu próprio quarto, em que sonha consigo mesmo consciente: o fato de lembrar-se do momento em que apagou a luz e dormiu evidencia isso; estabelecendo relação com esta lembrança o fato de que os sonhos distorcem os objetos. E a sensação de que "os olhos estão muito abertos" decorre da sobreposição da imagem do quarto coincidindo com a do sonho; isto é, não são os olhos que estão abertos, é a imagem do quarto muito nítida na memória que provoca a sensação de que se está visualizando os objetos com os olhos, produzindo a ilusão de se estar acordado. A ficção da realidade realiza no leitor o mesmo poder ilusório sensitivo. A sobreposição de cenas mimetizadas do ambiente real leva a crer que os olhos estão mais abertos do que os limites da experiência impõem: é apenas pela consciência das coisas e por prévio conhecimento de seus significados que a possibilidade de experimentar as articulações do sentido dos objetos como algo real ou idêntico ao real se torna possível. Ou seja, o realismo suprime da experiência sensitiva toda contingência que levaria o leitor a perceber que seus olhos estão fechados, prescrevendo a própria experiência e o estatuto do real que Ihe é adequado. Graciliano encontrou um meio de expor certos pormenores que não entrariam nesse tipo de literatura. A cena a seguir nos mostra exatamente isso:

\footnotetext{
Houve agora uma enorme pausa nessa agonia, todos os rumores se dissiparam, a vidraça escureceu, o soalho fugiu-me dos pés - e senti-me cair devagar na treva absoluta. Subitamente um foguete rasga a treva e um arrepio sacode-me. Na queda imensa deixei a cama, alcancei a mesa, vim fumar.
}

Nos contos realistas, personagens deslocam-se de um ponto para outro, ou desaparecem num ambiente e surgem no outro, como se varassem as páginas de uma revista em quadrinhos. Não os vemos em toda a inteireza, e este é o segredo de não ser os olhos, mas sim o sentido reposto pela consciência atuante do leitor, segundo a repetição convencional, o responsável pela sensação de presenciar a realidade. Mas a artimanha do conto de Graciliano quer revelar os aspectos que não aparecem nessa tendência: buscando-os numa experiência possivel (o sonhar que está acordado, ou num estado de insônia particular) para preencher estes espaços vazios da literatura realista, em que não há qualquer solução de continuidade, pode propor um paralelo entre normalidade e absurdo: entre o intervalo em que o personagem transita da cama à mesa, uma 
série de eventos completamente inusitados ocorre. Essa série representa o fluxo do pensamento, possibilitado pelo fato de que o personagem está no próprio ambiente da mente humana num instante em que nenhum mecanismo ou convenção social pode intervir. Ora, aí se encontra uma solução para a inclusão de elementos no contínuo espaço/tempo suprimidos pela literatura realista: o foguete que rasga a treva, entre o intervalo do deslocamento do personagem indo da cama à mesa, ainda que só pareça ser possível no sonho (surrealismo), também é parte do mundo: é parte de um contexto ainda maior em que se está inserido, em que, num instante em que alguém perde o sono, noutra parte do mundo, simultaneamente, aviões bombardeiam cidades e vilas. Ao ter superposto sonho/realidade simetricamente, esse conto mostra que os aspectos ditos reais são da mesma natureza dos do sonho, e que a literatura realista não chega a ser um conto de fadas diante da realidade:

Um silêncio grande envolve o mundo. Contudo a voz que me aflige continua a mergulharme nos ouvidos, a apertar-me o pescoço. Estremeço. Como é possível semelhante coisa? Como é possível uma voz apertar o pescoço de alguém? Rio, tento libertar-me da loucura que me puxa para uma nova queda, explico a mim mesmo que o que me aperta o pescoço não é uma voz: é uma gravata.

Ora, parece mais aceitável que uma gravata, índice do mundo social, do mundo do trabalho e do maquinismo,
Ihe dê um nó na garganta do que uma pergunta em que se toma uma decisão sobre o nada. Essa perspectivação simétrica dos níveis, da realidade e do sonho, revela que o mundo tido como real não é tão diferente dos absurdos do inconsciente: eles articulam-se conforme a mesma disposição dos indivíduos em aceitá-los razoáveis ou não aceitá-los, isto é, de permitir-lhes o nexo; pois, enquanto num uma palavra ou uma voz poderem apertar o pescoço é tido como loucura, no outro, os objetos simbólicos inanimados ganham vida e nos sufocam sem estranhamentos. $E$ a analogia entre a voz e a gravata, que poderia levá-lo à revelação do maquinismo, mostra apenas a necessidade de agarrarse em algo aparentemente palpável, que, no fundo, não difere muito do absurdo. Isso torna a decisão difícil ou pelo menos viciosa: "Sim ou não?" A pergunta, para bem dizer, é diabólica. Ela surge, pela manhã, junto com os feirantes que anunciam seus produtos, com o som dos automóveis e dos transeuntes na rua; põe o cidadão em posição de decidir-se, quando não há escolha. Ela é diabólica porque repousa na conveniência de agarrarse ao imediatamente aceitável sem que se perceba o inaceitável. É diabólica porque, quando o "maquinismo" apresenta um defeito, e nos põe de pé na hora errada, e no lugar errado da vida, assemelha-se a uma única e forçosa opção; torna-se uma ordem, perde o aspecto de "escolha". Só há uma escolha:

Desejaria conversar, voltar a ser homem, sustentar uma opinião qualquer, defender-me de inimigos invisíveis. As idéias amorteceram como a brasa do cigarro. O frio sacode-me 
os ossos. E os ossos chocalham a pergunta invariável: "Sim ou não? Sim ou não? Sim ou não?"

Não há dúvidas de que esse conto apresenta-se como contestação e denuncia certo modelo como insuficiente a atender às novas exigências de compreensão da atualidade. As transformações do mecanismo de dominação, que passa de imposição da necessidade imediata a ramerrão, não podem ser analisadas sem que o olhar modifique-se e perscrute suas possíveis falhas. $A$ literatura teria, portanto, essa função ao afastar-se de um dado padrão. Há uma nítida tentativa de interferir no ideal comum de que ser homem, no âmbito social, se harmonize com a de ser humano. Na insônia ou no sonho não há nenhum botão que desligue a perenidade do fluxo do pensamento; que, muito embora seja parte da condição humana, nos revela fragilizados e impotentes perante as exigências do universo construído com base num modelo mecanicista, utilitarista, em que a sensibilidade é substituída pela conveniência ou tomada como perturbação, em que ser homem não passa de uma paranoica pantomima que torna aquilo que é próprio do homem em deformação.

\section{"O Ladrão": no mundo da lua, no meio das casas, no meio da rua}

Como conto de abertura do livro, "Insônia" coordena todos os outros. O sentimento de inadequação do sujeito em certo contexto e a problematização da realidade pelo sonho vai ser invertido no segundo conto. Nelly Novaes
Coelho, em seu ensaio "Solidão e luta em Graciliano", vai utilizá-lo, como já dissemos aqui, como argumento de sua concepção da obra em conjunto, com finalidade diversa da que o conto teria em si. Para ela, o desfecho negativo das ações do ladrão se dera pela necessidade dele de comunicar-se e pela impossibilidade de realização amorosa no universo artístico produzido por Graciliano. Mas, após a leitura do conto de entrada, já não é mais possível pensar assim. Eis porque: a narrativa inicia-se com as seguintes observações:

\begin{abstract}
O que o desgraçouportoda a vida foia felicidade que o acompanhou durante um mês ou dois. Coisa estranha: sem nenhuma preparação, um tipo se aventura, anda para bem dizer de olhos fechados, comete erros, entra nas casas sem examinar os arredores, pisa como se estivesse na rua - e tudo vai bem. Pisa como se estivesse na rua. É aí que principia a dificuldade.
\end{abstract}

Ao ter repetido duas vezes que o personagem "pisa como se estivesse na rua", "de olhos fechados", temos todas as coordenadas do conto anterior de modo invertido. Enquanto no primeiro o sujeito tem a sensação de que os olhos estão abertos em função dos objetos coincidirem com os do sonho, aqui temos o sujeito em função de objetos que não coincidem, apenas inteligíveis no fluxo do pensamento, vistos de olhos fechados (ainda que os olhos orgânicos estejam abertos): é a mesma sobreposição, apenas invertida; em que, entre os objetos do passado e do presente, não haveria nenhuma solução de continuidade. E o 
erro, agora, e a revelação do maquinismo, se dá pela inadequação do sonho sobreposto a uma realidade em que os elementos não podem coincidir. Em verdade poderíamos dizer que os planos desse novato no mundo do crime frustram-se pela impossibilidade de se distinguirem seus projetos, delimitados no contínuo espaço/tempo, dentro de suas respectivas possibilidades de realização. Enquanto aquele que nele sonha intenta um objetivo, outro tenta adentrar no mundo do crime, em que, contraditoriamente, não há exatamente louros para coroá-lo, como se pisasse na rua. Daí a "felicidade" o ter desgraçado. O sucesso, nesse ramo, o leva para a cadeia. Por isso o narrador caracteriza as artimanhas do criminoso como indispensáveis e prejudiciais:

O indivíduo a que me refiro ainda não tinha alcançado essa andadura indispensável e prejudicial: indispensável no interior das casas, à noite; prejudicial na rua, porque denuncia de longe o transeunte.

Ocorre que o ladrão que o inicia, Gaúcho, parece ter percebido nele o desejo de coroar-se, à luz do dia, de uma fama nada adequada para quem quer ser bem-sucedido ao apagar das luzes: "(...) era bom que ele escolhesse profissão menos arriscada. Mas o rapaz tinha cabeça dura: animado por três ou quatro experiências felizes, estava ali, rondando o portão $(\ldots)^{\prime \prime}$. Assim acompanhamos o assalto, em que, de um lado, esse rapaz imagina o que vai pensar Gaúcho ao narrar-Ihe a proeza do crime; e, de outro, surgindo-lhe lembranças da infância, e até mesmo o esboço de um projeto de vida: conseguiria um bom dinheiro, mudarse-ia para outro lugar e abriria um comércio, onde engordaria contando notas atrás de um balcão. BrotaIhe, daí, insistentemente a imagem de uma menina loura, de tranças e olhos verdes, e que conhecera na escola, em flash aqui e acolá. E durante todo o trajeto do assalto isso lhe vai tornando à mente, até o dominar. Tendo entrado no quarto do casal, proprietários da residência, roubado uma carteira, saindo depois, vai topar com um quarto à meia luz, onde dorme uma moça com um dos seios à mostra. A imagem da garotinha da infância embrenha-se na dessa moça, superpondo-se; passa a imaginá-la de tranças e olhos verdes.

E daí em diante, até o desfecho medonho, não soube o que fez. No dia seguinte, já perdido, lembrou-se de ter ficado muito tempo junto à cama, contemplando a moça, mas achou difícil ter praticado a maluqueira que o desgraçou.

Aqui o narrador assume os fatos que se desenrolam e nos conta as consequências do beijo que despertara a moça, o que para o ladrão assemelha-se a um sonho tido durante a noite. $O$ novato no crime mal acredita que tenha tido a audácia de beijá-la. Nem entende o motivo que o levara à loucura. Mas o narrador nos dá a dica. Até o momento do encontro com a moça dormindo, ele sonhava acordado; e, após o beijo, o estardalhaço, precipita-se pela escada na fuga: repentinamente, no decorrer da execução do assalto, 
Acordara aí, mas adormeceu de novo, na queda que o lançou no andar térreo. Teve um sonho rápido na viagem: viu cubículos sujos povoados de percevejos, esteiras no chão úmido, caras horriveis, levas de infelizes transportando vigas pesadas na Colônia Correcional. (...) Despertou agarrado por muitas mãos. De uma brecha aberta na testa corria sangue (...) Um velho empacotado em cobertores gesticulava no meio da escada, seguro ao corrimão. E um grito de mulher vinha lá de cima, provavelmente a continuação do mesmo grito que lhe tinha estragado a vida.

Estranhamente, durante o assalto, estivera, na verdade, no mundo da lua (como nos indicara o narrador, "pisa como se estivesse na rua"). Iludido entre o que era e o que não era o mundo, realiza aí um tipo de sucesso que o desgraça. Desperta do sonho e cai num outro (que se realizará com a prisão). Isto é, os níveis de realidade são sonhos invertidos pela perspectiva do sujeito, e os objetos do mundo objetivo superpõemse ou não conforme os olhos que os veem ("anda para bem dizer como se estivesse de olhos fechados"). Os níveis sensitivos e perceptivos das possíveis realidades imbricadas indicam que o mesmo objeto participa de outras, não tendo autonomia enquanto dado objetivo e isolado do modo de ver do sujeito. Caso semelhante foi percebido por Rolando Morel Pinto ao analisar Angústia: dois tempos distintos fundem-se na simultaneidade da experiência do protagonista; um no passado, recordação da infância e adolescência na fazenda do avô; outro na frustração do relacionamento amoroso com Marina, na precariedade da vida e na necessidade de vingar-se de JuliãoTavares: "O passado assoma no plano do presente, trazendo consigo imagens há muito sepultadas na memória (...)" e "(...) a repugnância da presença do rival e a obsessão final traumatizante sucederam-se sem solução de continuidade."11

Para o ladrão não havia a possibilidade de realizar o sucesso amoroso que o acompanhara desde a infância, naquele momento, porque esse projeto só poderia se realizar no mundo da rua, conforme a perspectiva do cidadão regular. $E$ por um momento esse mundo tido como regular o domina como mundo natural do bandido e inverte, consequentemente, a chave da realidade, torna-se uma verdade de sonho. Ele já havia experimentado a sensação, anteriormente, de viver duas possibilidades de realidade simultaneamente no café da esquina, onde estivera momentos antes de avançar: "Seria bom recolher-se. Sorriu com uma careta e subiu a ladeira, colando-se às paredes. Como recolher-se? Vivia na rua. À medida que avançava a frase repetida voltou e logo surgiu o sentido dela." Isto é, era necessário pisar no mundo da rua como se estivesse no mundo da lua, sem perder o domínio das ações superpostas como idênticas em mundos diferentes. Ele deveria avançar para o furto como se caminhasse para um lar imaginário, mantendo sempre a realização do objetivo de furtar. Ora, o erro está claramente apresentado. E aí entra o elemento surpreendente do conto: "(...) uma vez que todo nosso equipamento para nos preparar para o futuro provém do

11 Rolando Morel Pinto, Graciliano Ramos: autor e ator, p. 126-127. 
passado, é redundante e irônico. Ou seja, somos todos principiantes na contingência, porque é a única coisa que podemos ser." ${ }^{12}$ Afora o determinismo, a contingência, ou o que ele não esperava encontrar nos aposentos da casa, era exatamente a memória objetivada em objetos. Seu projeto não era adentrar para o mundo do crime. Mas, sim, realizar-se enquanto indivíduo comum. A imagem da menina loura, de olhos verdes, representa o futuro que provém do passado e se realiza inesperadamente; várias vezes a imagem dela, antes de adentrar na residência, pipoca-lhe na memória como flashes. A coincidência não é exata entre essa imagem e o que vai encontrar lá dentro. Ou seja, o projeto real não estava no presente, furtar, mas numa realização esquecida, um outro sucesso, consequentemente, inadequado ao sucesso do furto.

"Só do acaso depende" é, naturalmente, uma frase curiosa. Para Proust não há como organizar, não há técnica que garanta acesso ao passado. O passado é revelado por coincidências que, em si mesmas, são insignificantes: um cheiro, uma melodia, um gosto. E não há como saber de antemão qual ou quando pode ocorrer. (...) o passado que está dentro de nós não está ativa e furtivamente planejando sua própria revelação, não está procurando atenção. Nem mesmo (...) está aguardando ser descoberto, embora esteja ali, em algum lugar, "nalgum objeto material", se tivermos bastante sorte ou azar para toparmos com ele. ${ }^{13}$

Topara com uma moça, dormindo com um dos seios à mostra. E ainda que soubesse que ela não era a menina da escola, isso não foi o bastante para mantê-lo firme em direção ao ideal imediato. Pelo contrário: "O maço de notas, adquirido facilmente, nem lhe dava prazer. Pisou a escada e estremeceu. As razões que o impeliram sumiram-se, ficou o peito descoberto". Pelo menos aí a ideia de que acordados não estamos sonhando ou que sonhando não estamos acordados é bem relativa. Graciliano, provavelmente, intui isso. Está claro que não se interessava em aprofundar-se em conhecimento sobre as vanguardas; que as considerava absurdas. Mas que de algum modo realizou parte das tendências ligadas a elas, muitos de seus textos comprovam.

A semelhança de alguns trechos desse conto - como o do momento em que o ladrão mentalmente diz a si mesmo que "era bom recolher-se" - com passagens de Ulisses de James Joyce é marcante. Neste, o contínuo capitado, na narrativa, como fluxo de pensamento é uma constante inversão de quem é o verdadeiro narrador. Um exemplo que ilustra a semelhança se dá com muita precisão após o enterro de Dignam, quando Bloom entra em uma lanchonete e enoja-se das pessoas que lá estão almoçando.

13 Idem, p. 46 
O senhor Bloom levantou dois dedos dubitativamente aos lábios. Seus olhos diziam:

- Não está aqui. Não o vejo.

Fora. Odeio gente porca comendo. ${ }^{14}$

O discurso do narrador, a cena e o pensamento de Bloom superpõem-se, mas não obedecem a uma ordem linear e hierarquizada conforme a estrutura tradicional; perceba-se que se o narrador em terceira pessoa indica o discurso indireto livre no trecho "Não está aqui. Não o vejo" - o que se constituiria como espécie de desmascaramento dos processos psíquicos do personagem -, este recurso logo em seguida vai ser desmentido ou se tornar "artificioso" com o surgimento do "Fora. Odeio gente porca comendo"; tal processo de esmagamento do narrador tradicional impede que o recurso de análise até então funcional de "discurso indireto livre" possa ser aplicado. E quem acompanha esse personagem, de passagem num dia comum, vai flagrá-lo constantemente como quem anda no mundo da lua. Isto é, a totalidade do sentido nas narrativas modernas se dá pela fragmentação dos atos, ações no tempo e no espaço simultaneamente; a totalidade só se torna objetiva pela dissonância das partes, a partir do que a representação ganha contornos não de realidade, mas de uma presença humana muito viva, nada linear ou comportada, e até mesmo podendo chegar a produzir sensação de deformidade. Ora, o que possibilitaria tal

14 James Joyce, Ulisses, p. 222. proximidade quando as experiências são tão distintas e distantes umas das outras? Vem bem a calhar lembrar dois aspectos do século XX que julgamos necessários compreender: o primeiro deles em virtude das premissas vanguardistas a que alguns autores ligaram suas propostas artísticas, como a relativa semelhança do sonho, do fluxo do pensamento, com o real (Breton); o segundo aspecto nos é dado pelo estudo de Erwin Theodor Rosenthal, cujo pressuposto teórico principal assenta-se em que "(...) a nossa realidade insegura e indeterminável (aqui denominada 'flutuante') apresentase em articulações multiformes. Essas articulações, por mais variadas que se revelem, apresentam espantosos pontos de contato (... $)^{\prime 15}$. Ou seja, assim como o sonho só é aparentemente caótico e sem sentido, tomado do ponto de vista superficialmente lógico, também a realidade; isso pôs em dúvida exatamente os meios anteriores de representar o objeto da percepção de modo linear, ordenado e claro, sob a perspectiva da linguagem cientificista do século XIX. E Rosenthal apresenta esse quadro a partir de literaturas aparentemente distantes umas das outras, "(...) que permitem se reconheça estruturas de pensamento semelhantes e possibilidades paralelas de conhecimento, relativando consideravelmente as diferenças nítidas existentes entre vivências bem distintas. ${ }^{16}$ Evidentemente não se trata de aludir aqui a um epifenômeno.

O caso é que o mundo modernizado modifica as relações em todos os sentidos e isso, é claro, não poderia de

5 Erwin Theodor Rosenthal, O universo fragmentário, p. 3. 16 Idem, ibidem. 
maneira nenhuma não afetar as artes de modo geral. Isto é, o modo de apreender a realidade ora apresentada e representá-la modificou-se com a modernização, com a automatização do trabalho especializado, em geral, dando novos contornos e possibilidades de experimentação tanto da realidade como da forma. Se a realidade ora segura, confortável, do mundo burguês, ordenado e linear, bastava até o princípio do século XX, ela deixa de ser possível após as Primeira e a Segunda Grandes Guerras, quando se torna nítido que a máquina, a tecnologia, toma proporções inimagináveis em termos de interferência no comportamento social. Bastando ver que a ideia de "maquinismo" em função da organização mental, psicológica e social do homem está aí, de cara, no primeiro conto do livro. O que significa que o modelo moderno é o novo regulador da percepção do homem no século $X X$, independentemente de ter ele se debruçado sobre as teorias de vanguarda ou propostas filosóficas modernas para a arte de modo geral; independentemente de sua concepção de modernidade ser positiva ou negativa. Assim, o simples fato de Graciliano ter-se colocado contra o modernismo levou-o a determinadas soluções literárias apenas contrárias à euforia e otimismo dos primeiros modernos. Percebese nitidamente que a modernização tecnológica, até então aspecto de otimismo, apresenta-se de modo desalentador e frustrante em Graciliano. Mas isso é só um problema de valor, não de técnica.

"A testemunha": entre o relato da verdade e a verdade do relato
O romance, desde os inícios do século, vem abandonando nitidamente os caminhos da narrativa aprazível de tempos passados, procurando abranger a nova realidade, inicialmente em algumas obras experimentais, e mais recentemente em maior escala. Essa nova experiência da realidade liga-se intimamente a um renovado sentimento lingüístico, que - libertado das limitações do pensamento lógico, científico e da análise factual - se projeta no mundo como possibilidade ou tentativa de uma nova e genuína expressividade. ${ }^{17}$

É notável como a crítica deixou praticamente intocados tão excelentes contos: verdadeiros lotes de exploração de novas possibilidades de compreensão de que o modernismo não se limitou a inovações morfológicas ou sintáticas: incluem-se nele também experiências sensoriais antes impensadas. $E$ entre elas estava também a sensação desagradável de que se falasse pelos cotovelos sobre o nada à medida que o testemunho presencial ou vivenciado dos fatos, em termos de uma literatura engajada socialmente, superasse em importância e preocupação os processos estéticos e estilísticos das obras. "A testemunha" de Graciliano é um exemplar dessa tendência de, nas palavras de Rosenthal, "tentativa de uma nova e genuína expressividade". Gouveia - chamado a depor como testemunha de um crime ocorrido na vizinhança - é o protagonista

17 Idem, p. 37 
desse conto espantoso. "Como a audiência não tinha começado, (...) conversou um instante com o oficial de Justiça". Arrelia-se. A intimação determinava o início às dez horas. Chegara um pouco antes, e apenas o oficial de Justiça e um servente ali se encontram. A expectativa inicial é de que se vá narrar a história de um crime, de qual tomaremos conhecimento através dos depoentes, dos acusados, do promotor e dos advogados. Expectativa que marca uma concepção literária tradicional; que habilmente seria atendida se estivéssemos diante de obra não moderna. E é por motivo desse último detalhe que o típico realismo esmorece. $O$ conto não conta a história do crime, mas a história de um julgamento de crime e de uma intrincada rede de fantasia da verdade, constituindo-se verdadeiro carrossel pantomímico da representação da reconstrução da verdade, a pondo em perspectiva como mutação. Os elementos contextuais do julgamento ganham vida por si mesmos: enquanto tudo aponta para o eventual assassinato, o menor gesto, no ar, vai conotar exatamente o oposto.

Gouveia não é testemunha de nada. Ficamos logo de cara sabendo que ele "(...) Escrevia umas coisas que prometiam gasto de papel. De repente a mulher, perturbada, abrira a porta da saleta:-Acho que mataram o vizinho aqui da esquerda." Após a notícia dada pela esposa, interrompe a composição de um período, um pouco indiferente à novidade. E como ela the repetisse a informação, "(...) erguera-se, chegara à janela, vira ajuntamento na calçada, um carro e a cabeça do chefe de polícia (...)". Do fato em si fica sabendo mesmo pelos jornais, no outro dia. E, em seguida, espantosamente, apresenta-se ali no tribunal como testemunha, desconfiado de que tenha sido alvo de intrigas dum suposto desafeto. Entretanto, porque a verdade ou o testemunho não vai sugerir realismo, passa a engendrála mentalmente a partir dos fragmentos presenciados por ele, juntamente com o que lera no jornal. Em síntese, contar a verdade o tornaria réu.

- Estupidez.

Afastou o depoimento que se esboçava, quase todo baseado em noticiários, porque realmente só percebera a multidão, barulho, um carro e frontaria do chefe de polícia.

E a partir daí, basicamente, até a leitura dos autos, veremos os esforços do personagem para evitar as incoerências que a verdade pura provocaria: "O que vira no jornal não combinava (...), havia na história incongruências e passagens obscuras. Quebrava a cabeça tentando harmonizar as duas versões; como não era possível, resolveu sapecar uma delas." Não seria esta uma das preocupações do ideal realista de representação? Continuemos. Acrescente-se ao embaraço do protagonista o fato de que um dos advogados, no seu imaginário, Ihe é antipático. Um tal dr. Pinheiro. E que o cerimonial do julgamento, perguntas acerca do nome, profissão, estado civil, soouIhe imediatamente humilhante porque o advogado dera um piparote no ar antes de começar a interrogá-lo: 
O inseto levantou os ombros indignado. (Provocação tola: Dr. Pinheiro era um caranguejo.) Torceu a cara, fungou, lá foi escorrendo que se chamava Gouveia, trabalhava na imprensa, tinha trinta anos, sabia ler e escrever. As perguntas desnecessárias constrangiam-no, amesquinhavam-no. Atrapalhava-se (...) Falavam-Ihe do crime agora, mas com palavras antigas, algumas evidentemente mal empregadas, outras de significação desconhecida. Hesitou, e o juiz recomendou-Ihe tento. Assustou-se, resolveu bridar a língua. Possivelmente dissera não quando era preciso dizer sim, e por isso the avivam a atenção.

Do porquê do assassinato ficamos completamente à distância. Mas percebemos que, se havia algum nexo na história que deveria ser contada, ele foi posto de lado em função de uma concepção de veracidade do relato mais condizente com a ficção do que com a verdade. Lembrando o que Barthes entende como originalidade, mas que, para nós, tem a ver mais com a verossimilhança.
Um amigo acaba de perder alguém que ele ama e eu quero dizer-Ihe minha compaixão. Ponhome então a escrever-lhe espontaneamente uma carta. Entretanto, as palavras que encontro não me satisfazem: são "frases" (...); digo-me então que a mensagem que quero mandar a esse amigo (...) poderia em suma reduzir-se a uma simples palavra: Condolências. Entretanto, o próprio fim da comunicação a isso se opõe, pois essa seria uma mensagem fria, e, por conseguinte inversa, já que o que eu quero comunicar é o próprio calor de minha compaixão. Concluo que para retificar minha mensagem (isto é, em suma, para que ela seja exata) é preciso não só que eu varie, mas ainda que essa variação seja original e como que inventada. $(\ldots)^{18}$

Uma das considerações que se pode tirar aqui, com Barthes, é a de que a "língua"/mensagem, enquanto produtora de sentido, ao se isolar de sua matriz mental de elaboração, significa sob novas condições (digamos de modo geral que sob as condições materiais das diversas situações em que se insere). Isto é que permite a inversão do significado e variabilidade da mesma mensagem. No instante em que Gouveia deixa de se ocupar com o fato e, precisamente, passa a pensar no veículo de transmissão do fato como mais importante, sua perspectiva de realidade deixa de ser a objetividade, passando a ser o como ela se torna possível. É curioso que esse conto tenha sido inventado a partir da própria invenção da verdade. E não só o Gouveia vai inventar, também o promotor, o advogado e juiz vão engendrando com ele algo que provavelmente convenceu não só à audiência, por mais que não tenha outra ligação senão com o momento e com o que passou a existir ali; portanto, não foi o fato anterior à audiência,

18 Roland Barthes, Crítica e verdade, p. 18-9 
precisamente presenciando o objeto da verdade: o carro de polícia, a multidão e a frontaria do chefe de polícia soaria falsificação se fossem descritos sob o rigor do ideal de realismo (o que se afasta completamente do senso comum de que Graciliano apenas valorizava a literatura presencial, que tirasse desse tipo de experiência prática sua matéria).

A sensação que fica, afinal, é a de que a verdade é uma invenção, que soa como verdade ao se adequar aos ouvidos que dela se servirão, conforme seus próprios propósitos. Contudo, essa invenção não passa incólume à consciência: sua virtualidade fica esquecida, ganhando status de realidade objetiva e vivida:

A amolação da audiência entrou-lhe no espírito - o tique-taque da máquina, o chiar dos papéis, as frases antiquadas, os cochilos, o caranguejo enorme levantando a pata enorme. Empalideceu e encostou-se a um muro, tremendo, o coração aos baques e o estômago embrulhado.

O conto termina aí com Gouveia nauseabundo, cambaleando ao longo de um muro, evidenciando que, ainda que soubesse que o tribunal, o júri, fosse "(...) Teatro, palhaçada, tudo palhaçada. Besteira amolarse, diria meia dúzia de palavras (...)", a representação o afeta completamente. Eis aí o motivo de a realidade, no século $X X$, insegura, indeterminada, "flutuante", não se adequar mais aos modelos realistas, naturalistas e positivistas do fim do século passado. Não é mais a realidade que nos interessa, mas como essa realidade se torna possivel e nos afeta como verdadeira realidade. Daí as considerações de Otto Maria Carpeaux sobre os escritos de Graciliano levarem-no a distinguir a realidade apresentada por Graciliano como "não deste mundo": "(...) É preciso destruir o mundo exterior, para salvar a alma. A realidade, nos romances de Graciliano, não é deste mundo. É uma realidade diferente. ${ }^{\prime 19}$

\section{Em síntese}

Há pouco tempo atrás, a Astronomia só considerava parte do universo o imediatamente visível. Atraía-se pelas estrelas, galáxias, nebulosas etc. Observações mais detidas do sistema intergaláctico vieram mostrar que os espaços considerados vazios do universo participavam consideravelmente na estruturação do todo; explicando o motivo de estar o universo em expansão. E isso graças a teorias construídas por cientistas, como Einstein, altamente conservadores em relação a um universo dinâmico. Suas conviç̧ões de um universo estático, fixo, caíram por terra assim como, ironia, suas próprias descobertas contribuíram para isso. Fatos desse tipo concorrem em outras áreas do conhecimento, porque não podemos controlar os saberes ou ordená-los que digam apenas o que desejamos. E Graciliano Ramos, ainda que considerasse o Modernismo uma frescura, não pôde evitar sua participação na construção da arte moderna. Não parece razoável confiar completamente no que dissera sem que se reveja todo o contexto de

19 Otto Maria Carpeaux, "Visão de Graciliano Ramos", p. 30. 
sua produção. É que muitas vezes se fizeram longas considerações contrárias a isto ou àquilo para chegarse ao mesmo e idêntico ponto de convergência. Muito provavelmente Mário de Andrade, Oswald de Andrade e Graciliano Ramos, diferentemente na técnica como em suas trajetórias, procurassem por vias aparentemente diversas atingir o mesmo fim. Graciliano Ramos, pelo menos em parte, envereda-se para a reinvenção da linguagem dos contos, apesar da obediência à vernaculidade da língua, com o fito de humanizar a arte, não de ser fiel à verdade. O diálogo, por exemplo, naquele tribunal de "A testemunha", foi resumido a advérbios: "perfeitamente", "não precisamente" e "naturalmente", "sim" ou "não".

Naturalmente, disse Gouveia.

Naturalmente, bateram no teclado dedos moles.

Alinguagemaíassume um carátergestual, pantomímico, em termos comunicativos, que significa teatralmente, não sendo mero veículo do significado. Há uma nítida diferença - já apontada naquele trecho de Ulisses entre o discurso direto "Naturalmente, disse Gouveia" e o "Naturalmente, bateram no teclado dedos moles": este último deixa de ser componente humano - não é verbal, é maquinismo, língua de máquina - marcando a passagem do que ele significaria no contexto do tribunal para o significado mecânico da linguagem jurídica. E esse plano que recobre o texto gesticula-se como um a voz "Sim ou não?" aperta o pescoço do protagonista de "Insônia", no mundo de Graciliano a palavra "cão" é capaz de morder. As palavras estão ligadas à experiência sensitiva de forma tão visceral que não se podem distinguir, enquanto veículo da comunicação humana, do humano. Caso talvez mais difícil de explicar por abstrair em vez de concretizar a linguagem. A simples concretização da língua falada, aliás, era para Graciliano uma franqueza prejudicial não só ao Modernismo como a alguns autores de seu tempo preocupados em ser fiéis à verdade. De todas nossas considerações, é evidente a necessidade de renovar-se ou até mesmo inovar as análises críticas da obra desse autor; arriscar-se nos espaços vazios deixados pela crítica de então.

\section{Referências bibliográficas}

BARTHES, Roland. Crítica e verdade. São Paulo: Perspectiva, 2003.

BRETON, André. "Manifesto do surrealismo" In: TELES, Gilberto Mendonça. Vanguarda européia e Modernismo brasileiro: apresentação dos principais poemas, manifestos, prefácios e conferências vanguardistas, de 1857 até hoje. Petrópolis: Ed. Vozes, 1977.

CANDIDO, Antonio. Ficção e confissão: ensaios sobre Graciliano Ramos. Rio de Janeiro: Ed. 34, 1992. 
CARPEAUX, Otto Maria. "Visão de Graciliano Ramos" In: BRAINER, Sônia (org.) Graciliano Ramos, Coleção Fortuna Crítica. Rio de Janeiro: Civilização Brasileira, 1978.

COELHO, Nelly Novaes. "Solidão e luta em Graciliano" In: BRAYNER, Sônia (org.) Graciliano Ramos, Coleção Fortuna Crítica. Rio de Janeiro: Civilização Brasileira, 1978.

FACIOLI, Valentim A. "Dettera: ilusão e verdade - sobre a (im) propriedade em alguns narradores de Graciliano Ramos". In: Revista do Instituto de Estudos Brasileiros n. ${ }^{\circ} 35$, p. 43 a 68, São Paulo, 1993. (Cf. p. 49)

JOYCE, James. Ulisses. trad. Antônio Houaiss. Rio de Janeiro: Civilização Brasileira, 2008.

LAFETÁ, João Luis. "Três teorias do romance: alcance, limitações e complementaridade" In: A dimensão da noite $e$ outros ensaios. São Paulo: Duas Cidades; Ed. 34, 2004.

PHILLIPS, Adam. O flerte. São Paulo: Companhia das Letras, 1998.

PINTO, Rolando Morel. Graciliano Ramos: autor e ator. Assis, São Paulo: Ed. da Faculdade de Filosofia, Ciências e Letras de Assis, 1962.

RAMOS, Graciliano. Insônia. São Paulo; Rio de Janeiro: Record: Altaya, (s.d.)
ROSENTHAL, Erwin Theodor. O universo fragmentário. trad. Mário Fleicher. São Paulo: Ed. da Universidade de São Paulo, 1975.

VERDI, Eunaldo. Graciliano Ramos e a crítica literária. Florianópolis: Ed. da UFSC, 1989. 